\title{
Parathyroid hormone related protein and interleukin- 6 mRNA expression in larynx and renal cell carcinomas from normocalcaemic and hypercalcaemic patients
}

D H Schweitzer, I L A Boxman, C W G M Löwik, J H J M van Krieken, M G Weissglas, R J Baatenburg de Jong, S E Papapoulos

\begin{abstract}
Aims-To determine the expression of parathyroid hormone related protein (PTHrP) and interleukin-6 (IL-6) mRNAs and their possible relation in malignant tumours, derived from patients with and without hypercalcaemia, commonly associated with humoral hypercalcaemia of malignancy.

Methods-PTHrP and IL-6 mRNA expression was studied by northern blot analysis in tumour specimens from 13 consecutive patients. Six patients (two with hypercalcaemia) had squamous cell carcinomas of the larynx and seven (one with hypercalcaemia) had renal cell carcinomas.

Results-There was no relation between the histological features of the tumours and the expression of either PTHrP or IL-6 mRNAs. PTHrP mRNA was detected in all squamous cell carcinomas, expression being highest in the two patients with hypercalcaemia. In the renal cell carcinomas PTHrP mRNA was expressed only in the patient with hypercalcaemia. IL-6 mRNA was detected in nearly all tumours studied but there was no apparent relation between its expression and that of PTHrP mRNA or serum calcium concentrations.

Conclusions-PTHrP mRNA expression is increased in patients with hypercalcaemia but is not related to IL-6 mRNA expression. The results suggest a quantitative relation between PTHrP gene expression and hypercalcaemia, and imply that different mechanisms account for this expression in squamous and renal cell carcinomas.

( $f$ Clin Pathol 1995;48:896-900)
\end{abstract}

Keywords: Parathyroid hormone related protein, interleukin-6, squamous cell carcinoma, renal cell carcinoma.

Department

R J Baatenburg de Jong

Correspondence to:

Dr S E Papapoulos.

Accepted for publication

13 March 1995
Parathyroid hormone related protein (PTHrP) is a major pathogenic factor of the syndrome of humoral hypercalcaemia of malignancy
(HHM) ${ }^{1-3}$ Earlier studies have reported the presence of PTHrP mRNA exclusively in tumours from patients with HHM. ${ }^{45}$ However, it was later demonstrated, by both immunohistochemistry and in situ hybridisation, that epithelial tumours most commonly associated with HHM but obtained from normocalcaemic patients may also express $\mathrm{PTHrP}^{6-9}$ These findings raise questions about the modulation of PTHrP gene expression in patients with hypercalcaemia and suggest that other factors may also be involved in the development of this condition. ${ }^{3}$ Previous studies in our laboratory have shown that the production and expression of PTHrP mRNA by squamous cell carcinoma cell lines could be enhanced by co-culturing these cells with fibroblasts. ${ }^{11}$ It may be that local soluble factors produced during the interaction between the epithelial and mesenchymal cells are responsible for the increased production of PTHrP. Such factors include cytokines and we recently showed that interleukin-6 (IL-6) production by fibroblasts is greatly enhanced during co-culture with keratinocytes by IL-1, which is secreted by most epithelial cells including squamous cell carcinomas. ${ }^{12}$ Interleukin-6, which stimulates osteoclast formation, ${ }^{1314}$ is also a hypercalcaemic factor ${ }^{15}$ and recently co-secretion of PTHrP and IL-6 has been reported in hypercalcaemic nude mice bearing a human renal cell carcinoma ${ }^{16}$ and in a patient with phaeochromocytoma and $\mathrm{HHM} .^{17}$

To examine the possible relation between PTHrP and IL-6 in malignant tumours, we studied the expression of the two peptides by northern blot analysis in two types of tumours commonly associated with HHM. These were squamous cell carcinomas (larynx) and adenocarcinomas (renal cell) derived from patients with and without hypercalcaemia.

\section{Methods}

In this prospective study 13 patients (nine men (mean age $59 \pm 4$ years) and four women (mean age $70 \pm 6$ years)) were investigated. Six patients had histologically confirmed laryngeal squam- 
Clinical details of six patients with carcinoma of the larynx and seven with renal cell carcinoma

\begin{tabular}{|c|c|c|c|c|c|c|c|c|c|c|}
\hline $\begin{array}{l}\text { Patient } \\
\text { no. }\end{array}$ & Sex & $\begin{array}{l}\text { Age } \\
\text { (years) }\end{array}$ & $\begin{array}{l}\text { Primary } \\
\text { tumour }\end{array}$ & Stage & $\begin{array}{l}\text { Serum calcium } \\
\text { (mmol/l) }\end{array}$ & $\begin{array}{l}\text { Serum phosphate } \\
\text { (mmolll) }\end{array}$ & & $\begin{array}{l}\text { Tumour } \\
\text { percentage }\end{array}$ & $P T H r P / 28 S$ & $I L-6 / 28 S$ \\
\hline & & & & & & & $\begin{array}{l}\text { Squamous cell carcinoma (larynx) } \\
\text { (differentiation) }\end{array}$ & & & \\
\hline 1 & F & 68 & laryn $x^{a}$ & $\mathrm{~T}_{4} \mathrm{~N}_{0} \mathrm{M}_{0}$ & $2 \cdot 42$ & 1.05 & well & 50 & 46 & - \\
\hline 2 & $\mathbf{M}$ & 56 & laryn $x^{b}$ & & $2 \cdot 87$ & 0.95 & moderate & 50 & 955 & 155 \\
\hline 3 & $\mathbf{F}$ & 56 & laryn $x^{b}$ & $\mathrm{~T}_{4} \mathrm{~N}_{2} \mathrm{M}_{0}$ & $2 \cdot 46$ & 0.99 & moderate & 50 & 285 & 26 \\
\hline 4 & $\mathbf{F}$ & 71 & larynx $x^{c}$ & & $2 \cdot 98$ & 0.91 & well & 90 & 943 & 2 \\
\hline 5 & $\mathbf{M}$ & 70 & larynx $x^{a}$ & $\mathrm{~T}_{2} \mathrm{~N}_{0} \mathrm{M}_{0}$ & $2 \cdot 43$ & 1.02 & poor & 80 & 239 & 18 \\
\hline 6 & $\mathbf{M}$ & 62 & laryn $x^{a}$ & $\mathrm{~T}_{3} \mathrm{~N}_{1} \mathrm{M}_{0}$ & $2 \cdot 43$ & 1.08 & $\begin{array}{l}\text { moderate } \\
\text { Adenocarcinoma (kidney) }\end{array}$ & 60 & 209 & 5 \\
\hline & & & & & & & (nuclear grading/type) & & & \\
\hline 7 & $\mathbf{M}$ & 37 & renal $^{2}$ & $\mathrm{~T}_{3} \mathrm{~N}_{1} \mathrm{M}_{1}$ & $2 \cdot 39$ & $1 \cdot 20$ & G3/tubular papillary & 80 & - & - \\
\hline 8 & $\mathbf{M}$ & 56 & renal $^{a}$ & $\mathrm{~T}_{2} \mathrm{~N}_{\mathrm{x}} \mathrm{M}_{1}$ & $2 \cdot 96$ & $1 \cdot 27$ & G2/clear cell & 40 & 261 & 393 \\
\hline 9 & $\mathbf{M}$ & 69 & renal $^{2}$ & $\mathrm{~T}_{3} \mathrm{~N}_{\mathrm{x}} \mathrm{M}_{0}$ & $2 \cdot 45$ & 1.02 & G3/clear cell & 80 & - & - \\
\hline 10 & $\mathbf{M}$ & 53 & renal $^{a}$ & $\mathrm{~T}_{1} \mathrm{~N}_{0} \mathrm{M}_{0}$ & $2 \cdot 27$ & 1.02 & G2/clear cell & 90 & - & - \\
\hline 11 & $\mathrm{~F}$ & 83 & renal $^{2}$ & $\mathrm{~T}_{2} \mathrm{~N}_{\mathrm{x}} \mathrm{M}_{0}$ & $2 \cdot 41$ & $1 \cdot 12$ & G2/clear cell & 40 & 6 & 253 \\
\hline 12 & $\mathbf{M}$ & 79 & renal $^{2}$ & $\mathrm{~T}_{2} \mathrm{~N}_{0} \mathrm{M}_{0}$ & $2 \cdot 34$ & $1 \cdot 20$ & G2/clear cell & 90 & - & - \\
\hline 13 & $\mathbf{M}$ & 46 & renal $^{\mathbf{a}}$ & $\mathrm{T}_{2} \mathrm{~N}_{2} \mathrm{M}_{1}$ & $2 \cdot 51$ & $1 \cdot 20$ & G2/clear cell & 90 & - & 32 \\
\hline
\end{tabular}

a Specimens obtained from primary tumours, ${ }^{b}$ from primary metastates to lymph nodes and ${ }^{\mathrm{c}}$ from a recurrent metastatic tumour. ${ }^{*}$ Recurrent malignant disease. $\mathrm{N}_{\mathrm{x}}=$ absence in regional lymph nodes.

ous cell carcinomas and seven had renal cell carcinomas, one associated with Von HippleLandau's disease (retinal cerebellar haemangioblastosis). Tumour tissue specimens suitable for northern analysis were obtained at surgery. Tumours were classified according to the American Joint Committee on Cancer staging system. A nuclear grading system was also applied to the renal cell carcinomas. ${ }^{18}$

All patients underwent bone scintigraphy before surgery and none had skeletal metastases. Parathyroid hormone was undetectable in the plasma of the hypercalcaemic patients, excluding the possibility of concomitant primary hyperparathyroidism.
Immediately after excision of the tumours, tissue samples were taken for pathological examination and for the determination of PTHrP and IL- 6 mRNA expression by northern blot analysis. For the latter, specimens were immediately placed in liquid nitrogen and kept at $-70^{\circ} \mathrm{C}$ until analysis. Of the laryngeal tumours, three specimens were obtained from the primary tumours (patients 1,5 and 6), two from regional lymph nodes (patients 2 and 3) and one from a subcutaneous tumour mass in the neck (patient 4). All renal cell carcinoma specimens were taken from the primary tumours.

Total cellular RNA was isolated from tumours by grinding (one minute; Polytron, Kinematica,

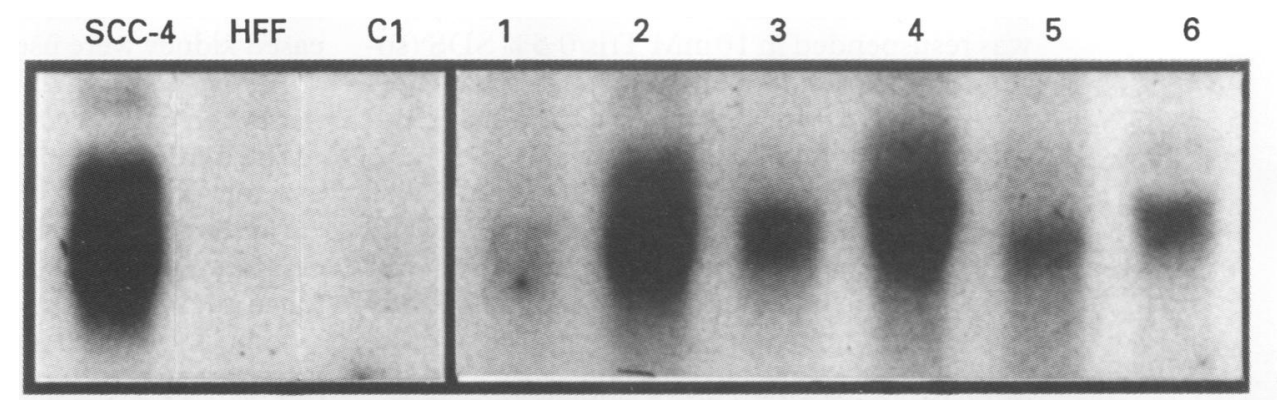

PTHrP
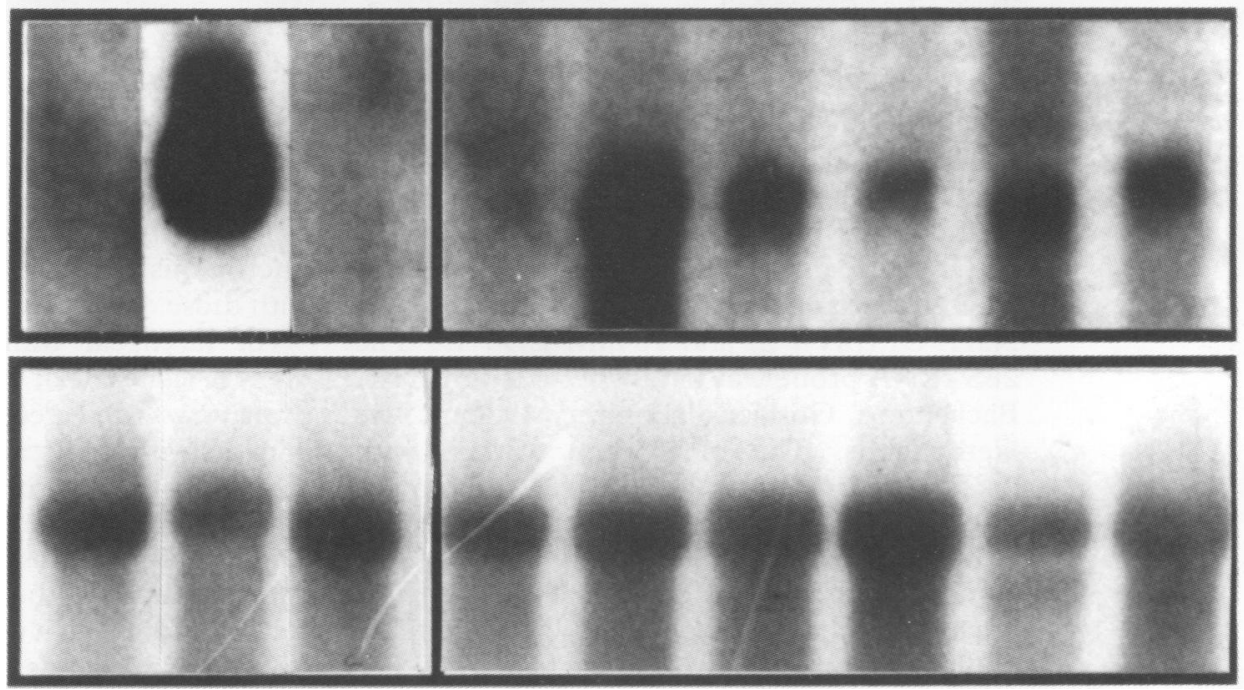

Figure 1 Northern blots of PTHrP and IL-6 mRNA expression in six patients with laryngeal carcinoma (anes 1-6). Lanes 2 and 4 contain $m R N A$ from patients with hypercalcaemia. SCC-4 and IL-1 stimulated human dermal fibroblasts were used as positive controls for PTHrP and IL-6 $m R N A$ expression, respectively. Lane C1 contains $m R N A$ from a patient with parathynid carcinoma, hypercalcaemia and metastases. 

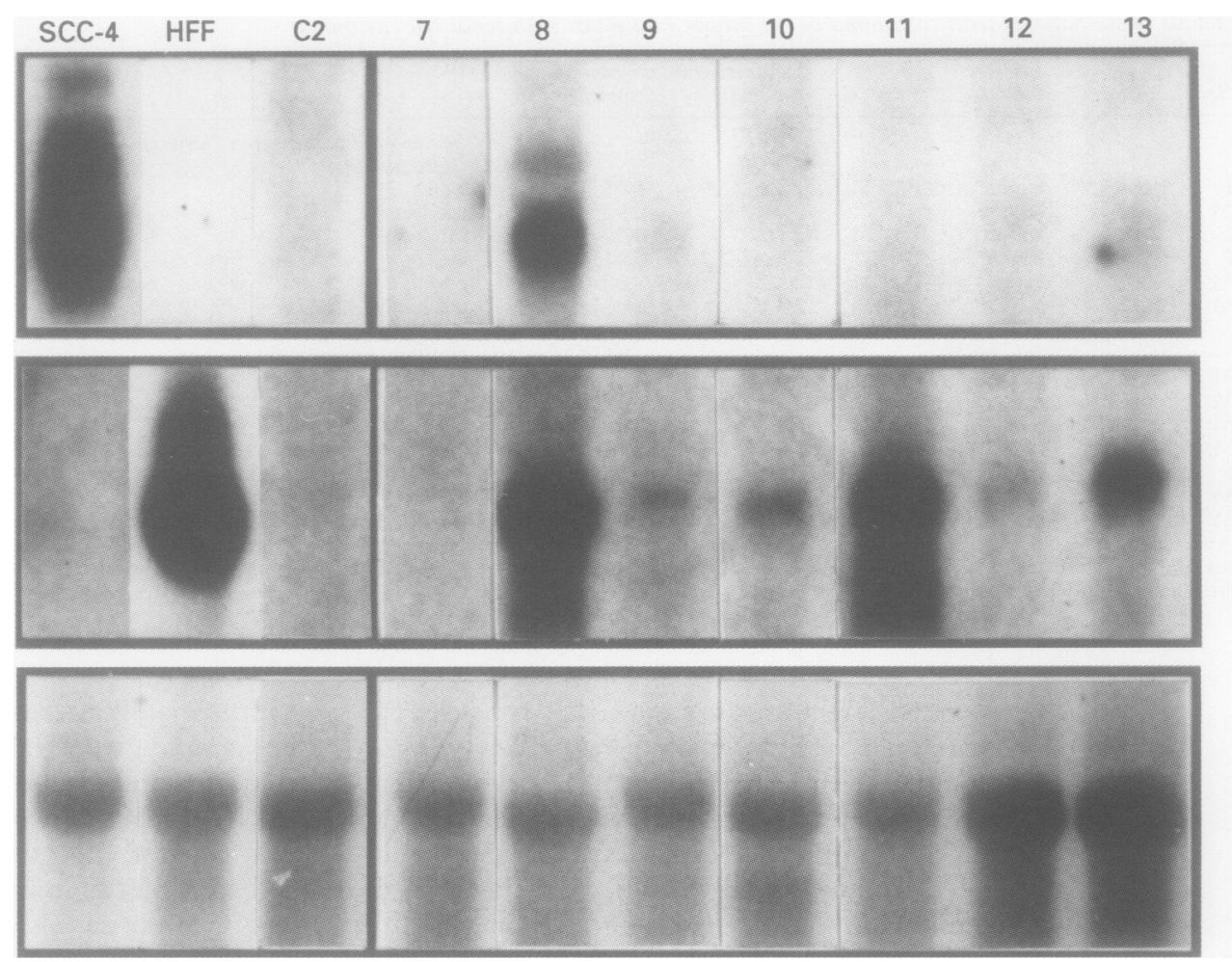

Figure 2 Northern blots of PTHrP and IL-6 $m R N A$ expression in seven patients with renal cell carcinoma (anes 7-13). The patient in lane 8 was hypercalcaemic. SCC-4 and IL-1 stimulated human dermal fibroblasts were used as positive controls for PTHrP and IL-6 mRNA expression, respectively. Lane C2 contains normal kidney tissue.

Switzerland) in ice-cold lithium chloride $(3 \cdot 3$ $\mathrm{M})$ /urea $(6 \cdot 6 \mathrm{M})$. After overnight incubation at $-20^{\circ} \mathrm{C}$, the homogenate was centrifuged at $10000 \times g$ for 30 minutes at $4^{\circ} \mathrm{C}$ and the pellet was resuspended in $10 \mathrm{mM}$ Tris $/ 0.5 \%$ SDS (sodium dodecyl sulphate (pH 7·7)). Total RNA was extracted with three cycles of phenol:chloroform:isoamyl alcohol (25:24:1) and subsequently precipitated at $-20^{\circ} \mathrm{C}$ in $70 \%$ ethanol/0.1 M sodium acetate $(\mathrm{pH} 5 \cdot 2)$. The pellet was resuspended in $10 \mathrm{mM}$ Tris $/ 1 \mathrm{mM}$ EDTA (pH 7.6). Total RNA was quantified by spectrophotometry at $260 \mathrm{~nm}$. RNA samples were analysed using electrophoresis on a $1 \%$ denatured agarose gel containing $7 \cdot 5 \%$ formaldehyde and transferred to a nylon membrane (Hybond N, Amersham, UK). ${ }^{19}$ The membranes were hybridised with $\mathrm{a}^{32} \mathrm{P}$ labelled cDNA probe for PTHrP ${ }^{20}$ (kindly provided by M Karperien, Hubrecht Laboratories, The Netherlands) and human IL-6 ${ }^{21}$ (kindly provided by Dr RA de Paus, University Hospital Leiden, The Netherlands) at $60^{\circ} \mathrm{C}$ in $7 \%$ SDS, $0.5 \mathrm{M}$ $\mathrm{NaHPO}_{4}(\mathrm{pH} 7 \cdot 2)$ and $10 \mathrm{mM}$ EDTA. ${ }^{22}$ The 28S rRNA probe was kindly provided by Dr C Backendorf, Gorlaeus laboratory, Leiden, The Netherlands. The blots were washed with $2 \times \operatorname{SSC}(0.30 \mathrm{M} \mathrm{NaCl}, 0.0310 \mathrm{M}$ sodium citrate), $1 \%$ SDS for one hour at $60^{\circ} \mathrm{C}$. Autoradiographs were prepared using Kodak XAR5 film and intensifying screens at $-70^{\circ} \mathrm{C}$. The intensity of the bands obtained was quantified photodensitometrically (Desaga CD60).

A squamous cell carcinoma cell line (SCC4) was used as the positive control for PTHrP mRNA expression ${ }^{11}$ and human dermal fibroblasts previously stimulated with IL-1 served as a positive control for IL- 6 mRNA expression. ${ }^{12}$ Malignant tissue from a patient with parathyroid carcinoma (not producing PTHrP) and normal renal tissue taken from a healthy area of a diseased kidney were used as additional controls.

All tissue specimens were evaluated by an experienced pathologist. An estimation was made of the total number of cell nuclei, lymphocytes and mesenchymal cells per tumour specimen.

Calcium, phosphate and albumin concentrations were determined in a blood sample taken the day before surgery using automated techniques and serum calcium concentrations were adjusted to an albumin of $42 \mathrm{~g} / \mathrm{l}$.

\section{Results}

Two of the six patients with laryngeal carcinomas and one of the seven patients with renal cell carcinomas were hypercalcaemic. The tumours of hypercalcaemic patients had no distinctive histological features when compared with those of normocalcaemic patients (table).

All laryngeal tumours expressed PTHrP mRNA (lanes 1-6; fig 1) but the highest expression was detected in the tissues from the two patients with hypercalcaemia (lanes 2 and 4; fig 1). Similarly, IL-6 mRNA expression was detected in all but one (lane 1) of the laryngeal tumours. By contrast, PTHrP mRNA was not detected in six of the seven patients with renal cell carcinoma but it was expressed in the patient with hypercalcaemia (lane 8; fig 2). IL-6 mRNA expression varied in the renal cell carcinomas. The normal renal tissue (lane C2) and the parathyroid carcinoma (lane C1) did not express either PTHrP or IL-6 mRNA. 
In the laryngeal carcinomas there was no apparent relation between PTHrP and IL-6 mRNA expression and the relative number of tumour cells per specimen (table); the number of specimens studied, however, is too small to allow definite conclusions to be drawn. Interestingly, in the renal tumours the highest IL6 mRNA expression was found in two clear cell carcinomas (patients 8 and 11), which also showed the abundant tumour invasion by mononuclear cells typical of tumour infiltrating lymphocytes. No such tumour infiltrating cells were detected in any of the laryngeal tumours.

\section{Discussion}

Previous studies using different detection techniques have provided conflicting data about a possible relation between PTHrP expression and hypercalcaemia in patients with malignant diseases. Cellular immunostaining with antibodies directed against PTHrP was positive in nearly all squamous and renal cell carcinomas examined but bore no relation to hypercalcaemia. ${ }^{6-9}$ Using in situ hybridisation, increased PTHrP mRNA expression was detected in hypercalcaemic patients with carcinoma of the cervix ${ }^{23}$ but not in another series of squamous cell carcinomas. ${ }^{9}$ These findings led the former authors to suggest that increased gene transcription contributes to the development of hypercalcaemia while the latter authors concluded that the clinical expression of HHM depends on the rate of secretion of PTHrP rather than on gene expression. In the present study, using northern blot analysis, we found that all laryngeal carcinomas expressed PTHrP mRNA but this expression was highest in the two patients with hypercalcaemia. Our data, therefore, support the hypothesis that the potential of a given squamous cell carcinoma for inducing HHM may reside in the quantitative capacity of the cells to express the PTHrP gene. ${ }^{24}$ In contrast to the findings in laryngeal tumours, PTHrP mRNA expression was not detected in any of the tumours from the normocalcaemic patients with renal cell carcinomas but it was clearly expressed in the patient with HHM. The possibility of low PTHrP gene expression in the renal cell carcinomas which could not be detected by northern analysis seems unlikely as only about $25 \%$ of cultured renal cell carcinoma cells appear to produce PTHrP and previous studies using more sensitive RNase protection analysis failed to detect PTHrP mRNA expression in a number of renal cell carcinoma cell lines. ${ }^{24}$

The present results, obtained in two histologically distinct malignancies associated with the syndrome of HHM, underline the importance of the relation between PTHrP and hypercalcaemia in malignant disease. These results also raise questions about the modulation of PTHrP gene expression by malignant cells. This is particularly relevant for laryngeal tumours in which PTHrP mRNA was detected in all tumours studied. We examined the possible involvement of $\mathrm{IL}-6$ as this cytokine has previously been reported to be co-secreted with PTHrP in hypercalcaemic nude mice bearing a human renal cell carcinoma and in a patient with HHM due to phaeochromocytoma, ${ }^{1617}$ is recognised as a hypercalcaemic factor ${ }^{13-15}$ and is produced by fibroblasts during co-culture with squamous carcinoma cells, an interaction previously shown to stimulate PTHrP production in vitro. ${ }^{10}$ All of the laryngeal carcinomas expressed both PTHrP and IL-6 mRNAs. However, no association between the degree of expression of these two factors and serum calcium concentrations could be demonstrated. The detection of both PTHrP and IL- 6 mRNAs in epithelial tumours known to be associated with HHM is intriguing and further studies of their relative importance in the development of hypercalcaemia are warranted. IL- 6 mRNA was also detected in renal clear cell carcinomas, confirming previous findings. ${ }^{2526}$ Expression was greatest in the tumours with the highest degree of infiltration by tumour infiltrating lymphocytes. This suggests an immunological response rather than an epithelial-mesenchymal cell-cell interaction. It may be that in squamous cell carcinomas which already express the PTHrP gene, local factors released from mesenchymal cells in response to tumour products modulate the production of the protein, while in the renal cell carcinomas different mechanisms are responsible for the expression of PTHrP by malignant cells and consequently for the development of hypercalcaemia.

In conclusion, our results confirm the importance of PTHrP in the pathogenesis of HHM by demonstrating the relation between the quantity of PTHrP gene expression and serum calcium concentrations. They also reveal clear differences between human squamous cell and renal cell carcinomas, suggesting that different mechanisms are responsible for PTHrP expression in these tumours.

We are grateful to Mrs Hetty C M Sips for expert technical assistance. These studies form part of a research programme supported by the Dutch Organisation for Scientific Research (NWO 900-541-191)

1 Broadus AE, Mangin M, Ikeda K, Isogna $\mathrm{KL}$, Weir EC, Burtis WJ, et al. Humoral hypercalcemia of cancer: Identification of a novel parathyroid hormone-like peptide. $N$ Engl $\mathcal{F} M e d$ of a novel parathy

2 Martin TJ, Mosely JM, Gillespie MT. Parathyroid hormonerelated protein: Biochemistry and molecular biology. Crit Rev Biochem Mol Biol 1991;26:377-95.

3 Mundy GR. Hypercalcemia of malignancy revisited. $f$ Clin Invest 1988;82:1-6.

4 Honda S, Yamaguchi K, Suzuki M, Sato Y, Adachi I, Kimura S. Expression of parathyroid hormone-related protein mRNA in tumors obtained from patients with humoral hypercalcemia of malignancy. $\mathcal{F} p n \mathcal{F}$ Cancer Res 1988;79: 677-81.

5 Ikeda K, Mangin M, Dreyer BE, Webb AC, Possilico, JT, Stewart $\mathrm{AF}$, et al. Identification of transcripts encoding a Stewart AF, et al. Identification of transcripts encoding a parathyroidhorm iated with humoral hypercalcemia of malignancy. $\mathcal{F}$ Clin Invest 1988;81:

Danks JA, Ebeling PR, Hayman J, Chou ST, Mosely JM, Dunlop J, et al. Parathyroid hormone-related protein: Immunohistochemical localization in cancers and in normal skin. F Bone Miner Res 1989;4:273-8.

7 Heath DA, Senior PV, Varley JM, Beck, F. Parathyroid hormone-related protein in tumours associated with hypercalcaemia. Lancet 1990;335:66-9.

8 Gotoh A, Kitazawa S, Mizuno Y, Takenaka A, Matsumoto $\mathrm{O}$, Kitazawa R, et al. Common expression of parathyroid hormone-related protein and no correlation of calcium level in renal cell carcinomas. Cancer 1993;71:2803-6.

9 Dunne FP, Lee S, Ratcliffe WA, Hutchesson AC, Bundred NJ, Heath DA. Parathyroid hormone-related protein (PTHrP) gene expression in solid tumours associated with normocalcaemia and hypercalcaemia. F Pathol 1993;171: 215-21.

10 Hoekman K, Löwik CWGM, v.d. Ruit M, Kempenaar J, Bijvoet OLM, Ponec M. Modulation of the production of 
parathyroid hormone-like protein in human squamous carcinoma cell lines by interaction with fibroblasts. Cancer Res 1990;50:3589-94.

11 Löwik CW, Hoekman K, Offringa R, Groot CG, Hendy GN Papapoulos SE, et al. Regulation of parathyroid homonelike protein production in cultured normal and malignan keratinocytes. F Invest Dermatol 1992;98:198-203.

12 Boxman I, Löwik C, Aarden L, Ponec M. Modulation of IL 6 production and IL-1 activity by keratinocyte-fibroblast interaction. $\mathcal{F}$ Invest Dermatol 1992;101:316-24.

13 Ishimi Y, Miyaura C, Jin CH, Akatsu T, Abe E, Nakamura Y, et al. IL-6 is produced by osteoblasts and induces bone resorption. Flmmunol 1990;145:3297-303.

14 Löwik CWGM, van der Pluijm G, Bloys H, Hoekman $\mathrm{K}$ Bijvoet OLM, et al. Parathyroid hormone (PTH) and PTHBijvoet OLM, et al. Parathyroid hormone (PTH) and PTHlike protein (PLP) stimulate IL-6 production by osteogenic cells: A possible role for IL-6 in osteoclast

15 Yoneda T, Nakai M, Moriyama K, Scott L, Ida N, Kunimoto $\mathrm{T}$, et al. Neutralizing antibodies to human interleukin 6 reverse hypercalcemia associated with a human squamous carcinoma. Cancer Res 1993;53:737-40.

16 Weissglas M, Schamhart D, Löwik C, Papapoulos S, Vos P, Kurth K-H. Hypercalcemia and co-secretion of interleukin6 and parathyroid hormone related peptide by a human renal cell carcinoma implanted into nude mice. $₹$ Umol 1995 ; 153:854-7.

17 Fukomoto S, Matsumoto T, Hirada S-I, Fujisaki J, Kawano M, Ogata, E. Phaeochromocytoma with pyrexia and $M$, Ogata, $E$. Phaeochromocytoma marked inflammatory signs: A paraneoplastic syndrome with possible relation to interleukin-6 production. $f$ Clin

18 Meyers GH, Fehrenbaker LG, Kelalis PP. Prognostic significance of renal vein invasion by hypernephroma. $f$ Urol
1968;100:420-3.

19 Sambrook J, Fritsch EF, Maniatis TE. Molecular cloning: $A$ laboratory manual. 2nd edn. Cold Spring Harbor, New York: Cold Spring Harbor Laboratory Press, 1989.

20 Mangin M, Ikeda K, Broadus AE. Structure of mouse gene encoding parathyroid hormone-related peptide. Gene 1990 ; 95:195-202.

21 Kaashoek JGJ, Mout R, Falkenburg JHF, Willemze R, Fibbe WE, Landegent JE. Cytokine production by the bladder carcinoma cell line 5637: Rapid analysis of mRNA expression levels using a cDNA-PCR procedure. Lymphokine Cytokine Res 1991;10:231-5.

22 Quax PHA, van Muijen GNP, Weening-Verhoeff EJD, Lund LR, Dan K, Ruiter DJ, et al. Metastatic behavior of human melanoma cell lines in nude mice correlates with urokinasetype plasminogen activator, its type-1 inhibitor, and urokinase-mediated matrix degradation. $\mathcal{F}$ Cell Biol 1991;115: kinase-m.

23 Liapis H, Crouch EC, Roby J, Rader JS. In situ localisation of parathyroid hormone like protein and mRNA in intraepithelial neoplasia and invasive carcinoma of the uterine cervix. Hum Pathol 1993;24:1058-66.

24 Broadus AE, Stewart AF. Parathyroid hormone-related protein; structure, processing and physiological actions. In Bilezikian JP, Levine MA, eds. The parathyroids; basic and clinical concepts. New York: Raven Press, 1994:259-94.

25 Takenawa J, Kaneko Y, Fukumoto M, Fukatsu A, Hirano T, Fukuyama $\mathrm{H}$, et al. Enhanced expression of interleukin-6 in primary human renal cell carcinoma. $¥$ Natl Cancer Inst in primary human

26 Gogusev J, Augusti M, Chrétien Y, Droz, D. Interleukin6 and TNFa production in human renal cell carcinoma. Kidney Int 1993;44:585-92. 